\title{
Domestic Support for Foreign Fighting: Attitudes Towards the Use of Violence Abroad
}

\author{
Eline Drury Løvlien ${ }^{1}[$
}

Received: 7 June 2020 / Accepted: 4 February 2021 / Published online: 10 March 2021

(C) The Author(s) 2021

\begin{abstract}
This study explores the phenomenon of foreign fighting through survey data gathered amongst Norwegian youths in 2015. Looking at two overarching explanatory models the article tests how grievances, criminality and more sectarian and religious factors affect more radical attitudes towards foreign fighting in Syria. Through this the article tests some central individual level factors to see how they impact support for foreign fighting in Syria, while also running alternative methodological approaches to test both the robustness of the initial findings and do some exploratory testing of non-responsive respondents in the multinomial models. The findings find support for factors such as past criminal behaviour and perceived deprivation in the form of self-reported socio-economic position, both of which are significant across the main models and in most of the alternative models. More abstract grievance measures, such as alienation and disillusionment more generally, provide more mixed findings. Hypotheses about a connection between religious identities and religiosity also finds support, with some indications that the sectarian nature of the Syrian civil war has a significant impact on attitudes amongst religious groups across the board. There is also a clearer sectarian dimension when studying those with higher levels of support for foreign fighting in Syria.
\end{abstract}

Keywords Foreign fighting $\cdot$ Jihadism $\cdot$ Europe $\cdot$ Grievances $\cdot$ Crime $\cdot$ Attitudes

\section{Introduction}

Foreign fighters who join armed struggles abroad, based on an ideological or religiously shared identity, represent a phenomenon with modern historical roots all the way back to the Spanish Civil War. The earliest examples of jihadi foreign fighters emerged in the early 1980s when Muslims from across the globe travelled to Afghanistan to take up arms against the Soviet army. The number of European

Eline Drury Løvlien

lovlien@uni-mannheim.de

1 School of Social Sciences, University of Mannheim, Mannheim, Germany 
foreign fighters in active conflict zones was relatively low until 2012 and not a priority for the European security and intelligence services (Bakker and de Bont 2016).

Within the broader definition of violence, participation in violence abroad in the form of foreign fighting can be seen as one specific type of political violence ${ }^{1}$ The specific nature of it can vary, depending on the context and group. For some the violence takes the form of insurgency or participation in more traditional civil war, while groups such as IS participate in acts of ethnic cleansing and terrorism.

The phenomenon of foreign fighting, though not new, became an increasingly potent topic for policymakers and researchers in the last decade, leading to a rapidly growing number of studies on the topic (Rostami et al. 2020). Much of these studies on foreign fighting have been primarily case studies and interviews with individuals who were planning to or had already taken part in violent actions abroad. This article builds on these findings by looking at factors identified in the radicalisation literature to see how they impact support for armed struggle abroad, specifically, the effect of previous criminal behaviour, socio-economic position and perceived alienation from Norwegian society on support for armed struggle abroad.

As Nilsson (2019) points out, the motivation for those who travel out changes over time and the process should not be seen as a static on, but rather as one that goes through several phases; from an initial stage of radicalisation "at home" to participation in foreign fighting and then as returnees for those who survive and chose to come back. More recent research also highlights the importance of empirical access to these different phases, which are dynamic processes that shift over time and as well as over geographical areas (Rostami et al. 2020). The aim of this study is to focus on the attitudinal aspects of this, namely domestic support for foreign fighting, rather than attempting to predict which individuals move from supporting foreign fighting to travelling out themselves.

The study is centred around three main contributions. Firstly, the study of political violence and violent attitudes has long been of interest to researchers in a broader social science perspective. The article uses a cross disciplinary theoretical framework ranging from psychology and political science to criminology to look at many of the earlier assumptions about the motivating factors Much of the research on radicals has, by its very nature, had a relatively small pool of recruits to study, which has in turn led to much of the research has taken the form of small-n studies. Earlier studies have also highlighted the need to include large-n studies that contribute by testing the consistency radicalisation on comparatively robust data (Skilicorn et al. 2012) and empirical studies on radicalisation in general (Rostami et al. 2020). An earlier study on attitudes towards foreign fighting and political violence conducted using the Young in Oslo data found a strong connection between general anti-social behaviour and more radical attitudes. This study builds on these earlier findings by looking more directly at criminal background and the effect of self-reported feelings of grievances, in the form of outsiderness and feelings of socio-economic disadvantage.

\footnotetext{
${ }^{1}$ See Kalyvas (2019) for a more in-depth look at the different manifestations of political violence globally.
} 
By testing these suggested explanatory factors in a large-n study the study is also able to highlight some useful methodological issues and contribute to further discussions on sensitive survey questions. The study contends with and including the respondent group that refused to respond to the question of foreign fighting. This methodological contribution opens up for further exploration of one of the issues with survey studies on sensitive issues, namely garnering truthful responses.

Because of the natural limitations of the used survey data this study is not able to capture the foreign fighters themselves. Rather it aims to study some of the common explanatory factors considered central for attitudes towards violence in general, as well as potentially motivating factors from previous research on violent radicalisation.

\subsection{Attitudes and Behaviour: Domestic Support for Foreign Fighting}

The individuals captured in this study do not themselves participate in violence abroad but rather measures a cognitive acceptance or willingness to support individuals who participate in acts abroad. Following the simile of a narrowing staircase as used by Moghaddam (2005) to explain the process of radicalisation, most individuals will find themselves at the ground floor where violence is viewed negatively. A much smaller segment of the population will move on to the next level of the narrow staircase that, by the end, leads to perpetration of violent acts by a very small subsample. Most individuals, even those with radicalised ideas will not end up at the top of the staircase, but still represent an interesting subject of study. The study takes a rationalist view of attitudes, as presented in Skilicorn et al. (2012), where attitudes and beliefs are viewed as measurable instruments (p. 933). The assumption is that attitudes vary within a population and that these attitudes affect peoples' tolerance of violence. In turn, external realities might change and change these individual attitudes and beliefs. These inhibitors can be seen as either external or personality based, that is to say either a psychological or economic approach to the process of radicalisation (Berman 2009; Skilicorn et al. 2012). Attitudes have been used in studies of violence as hypothetical constructs, which are determined by the internal value system of respondents (Ajzen and Fishbein 2005; Funk et al. 1999). The research on violent radicals has failed to provide any "standard" profile, which might in part be explained by the fact that radicalisation is not a static phenomenon but rather a dynamic process (McCauley and Moskalenko 2008; Nilsson 2019). The theoretical framework and earlier research applied in the study ranges from more traditional conflict literature, to psychology and criminology to look at many of the earlier assumptions about factors influencing more radical attitudes towards the use of violence.

The article will first define foreign fighting in the context of the Norwegian case, before delving into the previous research done on foreign fighting, as well on attitudes towards the use of violence. Following this, the theoretical framework of the article and the hypotheses will be presented. The data from the Young in Oslo survey will be presented in the methodology section, before presenting the models and findings. The study applies both linear and logistic regression, making it possible to 
test the initial results further and to consider the highly skewed distribution of the dependent variable. Before concluding the initial models will also be tested with some further robustness tests.

\section{The Foreign Fighter Context in Norway}

Foreign fighters can in the broadest sense be defined as "non-indigenous, non-territorialized combatants who, motivated by religion, kinship, and/or ideology rather than pecuniary reward, enter a conflict zone to participate in hostilities" (Moore and Tumelty 2008, p. 412). Kinship, following this definition, should be understood figuratively as a common identity marker. In the case of the Muslim foreign fighters, this common identity marker is their religious identity as (Sunni) Muslims. It would be erroneous to view the phenomenon as a new one, as it has historically manifested itself in a multitude of ways, across a broad range of ideologies and groups (Bakker et al. 2013; Hegghammer 2010b). But the phenomenon has become increasingly salient in the last decade with the intensified recruitment of young Europeans to militant groups in the Middle East and North Africa. Reports indicate that over 20,000 foreign fighters have joined militant groups in the war-torn areas of Iraq and Syria, with a significant portion of these coming from Europe (Neumann 2015). Between 2012 and 2014 the number of foreign fighters travelling from European countries increased exponentially, with some estimates seeing a tripling of cases in the threeyear period (Bakker and de Bont 2016).

This led to a growing concern within Europe that the sectarian conflicts in Syria and Iraq will destabilise the region and lead to further radicalisation amongst young Sunni Muslims in Europe (Nesser et al. 2016). This outflow of fighters has attracted much attention both in the media and amongst European security services, with increased attempts at understanding why individuals who have grown up in Western Europe, with little experience of violence themselves, were willing to travel to places such as Syria to fight. Even within this context of an internally peaceful Europe, Norway represents a very interesting case study. Norway has seen no major political upheavals or larger violent conflicts within its own borders since the end of World War II. In addition to this, the country is one of the wealthiest in Europe, with low levels of unemployment, very little absolute poverty, high levels of institutional trust and historically a very homogeneous population that over the last 40 years has become increasingly more heterogeneous (Steinkellner 2020; Vassenden 1997). Many of the grievance-based arguments put forward in the literature therefore do not explain why Norway has seen such a high per capita share of foreign fighters. Based on many of the assumed mechanisms behind radicalisation, Norway in many ways represents a "least likely" case when it comes to explanatory factors behind individuals travelling out to fight. In a wealthy Nordic welfare state, attitudes about issues such as alienation and disillusionment amongst Norwegian youths can provide fertile soil for studies on the connection between these factors, the criminal risk behaviour and willingness to participate in violence abroad. Norway has also seen a substantial outflow, per capita, of foreign fighters to the Syrian theatre of war (The Soufan Group 2015). 


\section{Previous Research}

While the aim of this study is to look at attitudes and support for foreign fighting more generally, most of the previous research done on foreign fighting focuses on the small group of radicalised individuals who have already taken steps to travel out to fight. Looking at attitudinal studies more broadly, there seems also to exist certain overlaps in the factors identified in these foreign fighter studies and in studies that deal with radical attitudes towards violence more generally.

The increased interest in foreign fighting as a phenomenon, following the invasion of Iraq and the Syrian Civil War, has led to an influx of case studies on the topic. Many of these case studies have taken the form of primary or second-hand interviews with former foreign fighters and were focused on providing descriptive or phenomenological studies of radicalised Europeans travelling out to fight (Bakker 2011; Marone 2016; Moore and Tumelty 2008; Nilsson 2019; Rostami et al. 2020). In addition to this, some country level studies have been done on the driving factors behind foreign fighting in Syria and Iraq (Pokalova 2019), as well an increased focus on the gendered dimension of these factors (e.g. Kvakhadze 2020). More recent research on Swedish jihadists has also furthered the understanding of underlying motivations and commonalities amongst those who travel out. Rostami et al. (2020) finds higher levels of general criminality amongst their sample of Swedish foreign fighters and connects this to previous numbers from Europol as well as Dutch findings ${ }^{2}$. A study of 242 European foreign fighters from earlier conflicts also found that significant portion of the radicalised individuals in their sample had previous run-ins with law enforcement Bakker. This represents a shift from what was seen in earlier periods in the USA where there was little evidence of criminal backgrounds amongst radicalised individuals (Silber and Bhatt 2007). Vidino points out that many of those who left for Iraq after the US-backed invasion in Iraq in 2003 were often individuals from poorer immigrant neighbourhoods, who were younger and had a previous history with the police (Committee on International Relations, 2005, p. 30). The Young in Oslo report, from which the empirical data in this article stem, indicates that overall the scale of criminal activity amongst teenagers in Oslo has been reduced significantly in recent years (Andersen and Bakken 2015). At the same time the previous study done on the Young in Oslo data found a significant association between general conduct and extremist attitudes, indicating that anti-social behaviour might play an important role in explaining who radicalises and who does not (Pedersen et al. 2017). The study found that extremist attitudes amongst Norwegian youths followed the outlines of what they described as an "outsider" position amongst those exhibiting extremist or radicalised attitudes toward political violence (ibid).

Countries such as the Netherlands and Belgium have been especially prominent in many of these case studies, most likely the result of their position as two of the main sender countries in Europe, per capita, of foreign fighters travelling to Syria and Iraq (The Soufan Group 2015). Two early Dutch studies focused on providing

\footnotetext{
${ }^{2}$ See Europol (2016) and Bakker and de Bont (2016)
} 
descriptive information on individuals travelling or planning to travel from Europe to Syria to fight $(2015,2014)$. A recurring theme in both studies was the focus on the radicalised individuals as young people with limited prospects which fits with the traditional relative deprivation literature (e.g. Stewart 2000).

While not directly dealing with the issue of foreign fighting, some of the research done on attitudes towards violence more generally has also found similar patterns. Collective relative deprivation was found in a Dutch study to more directly predict positive attitudes towards the use of violence in defence of religious or ethnic ingroup (van Bergen et al. 2015). The same study also found that these studied pathways to positive attitudes towards defensive violence, while impacted by sociopolitical contexts, also impacted differently across different Muslim youth groups indicating that it is difficult to draw any generalised assumptions about group identities as they are also complicated by malleable and inter-crossing identities amongst youths. Similar studies of attitudes towards violence have also found a connection between more positive attitudes and explanatory factors such as perceived injustice and feelings of group threats amongst the youth respondents (Doosje et al. 2013). Many of these studies, both foreign fighter case studies and more general attitudinal studies, have focused on grievances, often in the form of socio-economic and psychological factors, viewing those who leave to fight as belonging to the marginalised fringes of Western societies.

Dawson and Amarasingam (2017) have criticised this singular focus on grievances, which does not take into account that factors such as socio-economic grievances exist beyond those few individuals who choose to travel out of the country, indicating that grievances by themselves cannot explain why individuals radicalise and in rare cases leave. In addition to these socio-economic factors, a recent study of at-risk radicalised individuals found specific traits amongst radicalised adolescents. By comparing the social and psychological profiles of radicalised adolescents and adults, Oppetit et al. (2019) found that the younger sample of radicals had a higher percentage of female radicals, compared to the adult group and in general the adolescents seemed more psychologically vulnerable. A study of former or current foreign fighters from Denmark who joined militant Islamist groups in Syria and/or Iraq also touched upon this issue (Sheikh 2016). The Danish study argues that the decision to leave Denmark and take up arms in Syria has by and large been driven by grievances, but warns against ignoring the allure of sectarian factors such as the mythologising of "The State" and the possibilities that exist within armed struggle for revanchism and strengthening feelings of pride in relation to one's own identity (ibid). Focusing solely on domestic factors can therefore be detrimental for understanding motivations in context of the Syrian conflict.

The lack of larger empirical studies on attitudes towards foreign fighting, especially in the context of radical attitudes, might partly be explained in part by the lack of data on young Europeans and their attitudes. Larger cross-national surveys conducted in Europe have not focused on foreign fighting and attitudes regarding the use of political violence abroad, making the Young in Oslo data very novel and making further quantitative studies on the topic possible. A previous study using the Young in Oslo data found that anti-social behaviour was connected to attitudes about fighting in Syria (Pedersen et al. 2017), while this article will investigate this 
further by looking at the crime-radicalisation nexus which posits a possible connection between more common forms of crime and participation in what we traditionally call political violence.

\section{Theoretical Framework}

Foreign fighting as a phenomenon represents one specific manifestation of political violence with participation in violence abroad. Much of the literature on mobilisation in the context of conflict uses an understanding of grievances and opportunities to understand why some individuals have more radical attitudes towards the use of political violence, be it at home or abroad. Much of these explanatory factors, in the context of violent radicalisation in Europe, has sprung from the French sociological tradition (Dalgaard Nielsen 2010). Nilsson (2019) identifies two overarching explanatory models, one which views socio-economic explanations in light of cultural s factors, such as in the work of Gilles Kepel (2017), where the religious and cultural explanations are in focus. The other explanatory model, central to the work of Olivier Roy, views violent Islamist radicalisation as a manifestation of a more general violent nihilism, separate from cultural explanations $(2016,2017)$. The study uses this overarching theoretical framework to study radical attitudes as well, with the caveat that the studied respondents are not necessarily mobilised but rather uncover cognitive radicalisation.

\subsection{Grievances and Foreign Fighting}

The separation of religion from the radicalisation process has become increasingly common within radicalisation and terrorism research. Central proponents of this view, such as Olivier Roy and Rik Coolsaet, view modern jihadism as a manifestation of a specific youth subculture and gang mentality rather than as an expression of religious fanaticism. These European youths represent what Coolsaet describes as so-called no future youths who see themselves as marginalised within European societies, which in turn functions as a driver for violent radicalisation (2016, p. 3). Much of the previous literature on conflict mobilisation deals directly with these grievances, in effect experiences of deprivation within Europe that help to explain why certain individuals seem more open to being mobilised or desensitised to violent acts.

\subsubsection{Socio-Economic Identity}

Studies done on economic incentives for foreign fighters have been unable to identify any concrete economic rewards that help to explain recruitment to foreign fighting (Hegghammer 2013). The lack of any pecuniary reward is central in differentiating between foreign fighters and mercenaries whose allegiance is contingent on economic compensation. The lack of evidence for any motivation for foreign fighting stemming from economic rewards does not necessarily preclude all economic 
factors from playing a motivating role for those travelling out as a foreign fighter. As Hegghammer found in the case of Saudi foreign fighters, internal socio-economic marginalisation in the Kingdom of Saudi Arabia was one factor that helped to explain the flow of Saudis into terrorist organisations such as Al-Qaida in the late 1990s (2010a). Socio-economic grievances can function as potential factors, lowering the barrier for individuals who feel they have "less to lose". This connection between socio-economic grievances or feelings of disadvantages has been a common discussion in studies done on violent radicalisation in Europe (Dalgaard Nielsen 2010). Studies using data on inequality and poverty which have been aggregated at the national level have been used to argue that there is no clear connection between lower GDP and Gini coefficients as root causes of increased foreign fighters from certain European states (Benmelech and Klor 2016). Verwimp argues that it is rather the socio-economic structures in certain welfare states that create barriers for outsiders to take part in job markets and through this the benefits bestowed by welfare state systems (2016). If this explanation for radicalisation within Europe holds, it is also likely that it would be relevant for Muslim minorities within Europe which, as a group, are much more likely to be marginalised by these structures and to be socio-economically disadvantaged (Adida et al. 2010; Murshed and Pavan 2011). This is also highlighted by Stewart (2016), who looks at how political, economic and cultural status inequalities play a role in explaining violent conflict in non-Western contexts. Economic grievances are therefore likely to be important for understanding increased likelihood of support for travelling abroad to fight.

H1 Those who view themselves as economically disadvantaged are more likely to support violent participation in the Syrian war.

\subsubsection{Criminal Behaviour}

The focus on political violence as a strain of criminal behaviour has been afforded little focus within political science, which has traditionally seen political violence as a manifestation of ideological and political behaviour rather than as related to deviant or criminal behaviour patterns. Criminal gangs and jihadist groups seem to be picking members from the same recruitment pool, which fits with French research on the synergetic relationship between criminal activities and the increased risk of participating in violence (Basra and Neumann 2016; Roy 2016).

The Algerian Islamic Group (GIA) operating in France in the early 1990s was known to have recruits with a history of gang memberships, leading the French press to label the group's actions as "gangsterterrorism" (Basra and Neumann 2016, p. 28). In large part this definition seemed to stem from the very concrete criminal acts in which certain GIA cells were participating, such as gun/running and armed robberies. The use of criminal activities to fund terrorist operations is well known and stopping funding has often been used as a policy solution to hinder terrorist groups and curb their influence. In the case of the current wave of radicalised youths, it is not necessarily the use of criminal activities to fund the groups' operations but rather the criminal history of individuals within the groups that has raised red flags. Following Roy and Coolsaet's argument, people do not join ISIS and other jihadist 
groups because of their religious or ideological leanings but rather because of what these groups represent as a new avenue for deviant behaviour (Coolsaet 2016; Roy 2016).

It has been noted that the role of kinship and networks is important for understanding the current wave of foreign fighters and that these networks often operate in conjunction with criminal activity such as street crime and petty theft (Coolsaet 2016). Criminal background is also one of the main characteristics of the recent wave of foreign fighters from Europe. Where previous waves were driven by ideological or religious literacy, the current crop of recruits is both younger and less educated than previous iterations. Individuals with criminal backgrounds are overrepresented in groups such as Islamic State, which has led some researchers to talk about membership in radical jihadi groups as merely representing a new way of channelling criminal behaviour (ibid). To test this relationship between radical attitudes towards violence and previous history of violence, the following hypothesis has been included:

H2 Previous criminal behaviour increases the likelihood of supporting violent participation in the Syrian war

\subsubsection{Alienation and Disillusionment}

Another explanation is that fascination with the fighting in Syria and Iraq can function as an outlet for anger and dissatisfaction with life in European societies. Alienation is increasingly seen as an important part in understanding political attitudes and behaviours. Alienation occurs in response to many different exogenous factors, which might be pre-existing or self-imposed, but which all lead to the same end result, namely a sense of estrangement (Duffy 2009). Della Porta argues that associating with groups that operate outside mainstream society can stem from sentiments of alienation from mainstream society (1992). Looking at research done on communist groups in the 1950s, this participation or admiration can be explained by a deepening sense of alienation that destroys any hope of reform or change within the current political framework (1954, p. 369). Leaving to fight in Syria could therefore be seen as distancing oneself from the existing political system to embrace a new life "away" from the old. This interpretation of alienation as a force for protest is consistent with the original Marxist view in which alienation functions as a catalyst for radical attacks upon the existing social structure (Fromm 1962; Marx 1844; Ransford 1968). Following this, the presence of alienation, be it real or perceived, has also increasingly been seen in connection with radicalism and radical political behaviour (Schwartz 1973; Seeman 1959). Alienation has also been found to be associated with revolutionary activities and violent mass mobilisation such as riots (Ransford 1968). Outsiderness from Norwegian society represents a very fuzzy group, making it a very elusive concept to pin down.

Our first understanding aims to capture a sense of outsiderness from Norwegian society or not being accepted by the majority society, namely what Coolsaet calls "[...]feelings of exclusion and absence of belonging" (2016, p. 24). To test this the following hypothesis is included: 
H3 Feeling alienated from Norwegian society increases the likelihood of supporting violent participation in the Syrian war.

In addition to feeling alienated from Norwegian society, another dimension in this sense of not being part of society can be seen as a broader disillusionment with their countries of origin (Dawson and Amarasingam 2017).To test this the following hypothesis has been included:

H4 Feeling disillusioned with Norwegian society increases the likelihood of supporting violent participation in the Syrian war.

\subsubsection{Foreign Fighting and the Religious Dimension}

The role of religion in the radicalisation process is much debated within studies on political violence and has given mixed results as far as findings go. The religious aspects of religious terrorism are treated quite ambivalently within the literature, with no direct causal relationship between religion and political violence being found. At the same time research has grappled with the fact that religious justifications are prominent amongst those participating in jihad (Dawson 2017; Kepel 2017). This erasure of religion as part of the explicans for religious terrorism and the tendency to ignore the underlying religious motivations as expressed by the jihadists themselves have been criticised by some researchers (Dawson 2018).

By downplaying the role of religion as a motivating factor there is a danger of ignoring what could potentially be a central mediating factor in understanding why individuals go to Syria and Iraq as foreign fighters (ibid). Most individuals who face socio-economic grievances do so without viewing armed participation in the Syrian theatre of war as a fruitful avenue to explore, meaning that grievances are, by themselves, not able to explain why individuals choose to view participation in violence abroad favourably. Drawing on literature on jihadist extremism, this view places the current foreign fighters within an older tradition of jihadist fighters who travel abroad to fight alongside "brothers in arms" in conflict zones (Kepel 2003). The participation in the Afghan jihad against the Red Army in the 1980s was proclaimed to be the responsibility of Muslims everywhere and part of so-called defensive jihad against the infidels. Since the end of the Cold War the same phenomenon has been observed in conflicts across the Muslim world, ranging from the Chechen conflict to Somalia in the early 2000s. This use of religious rhetoric and jurisprudence tied the participation in armed struggle to religious theology and sectarian identities indicating that religion at some level functions as a driver in the radicalisation process (ibid). To test this the following hypothesis is included:

H5 Higher levels of religiosity increase the likelihood of supporting participation in violent participation in the Syrian war. 
Because of the strong sectarian element to the fighting in Syria and Iraq, the assumption is that young Muslims are especially vulnerable to thoughts of travelling abroad to fight. As mentioned in the introduction, there are also cases of ethnic Norwegians who have travelled to Syria and Iraq to fight, but these individuals have usually converted to Islam before travelling. To test this the following hypothesis is included:

H6 Individuals who identify as Muslim are more likely to support participation in violent participation in the Syrian war.

\subsubsection{The Compounding Effect}

Another possible explanation is that the grievances and social factors are not by themselves necessarily significant predictors but rather interact with more cultural factors, creating a compound effect. In this case, the religious aspect can be seen rather as supporting factors to the already present social factors mentioned above. Roy claims that there is a rapid return or conversion to religion in the case of radicalised individuals (Roy 2015, p. 3). The shift from criminality to a religious identification can be found in many of the jihadist case studies, where individuals with previous run-ins with the law rapidly "find God" as part of the radicalisation process (ibid). To test this, the following hypothesis is included:

H7 More religious individuals with criminal backgrounds are more likely to have positive attitudes about participation in violent participation in the Syrian war.

\section{Data and Methodology}

The article uses survey data gathered for the Young in Oslo study which is part of a larger, biennial national youth survey. Using a module on extremism from the 2015 wave which was administered only in the Oslo region. The data were made available through the Norwegian Social Research Institute (NOVA) (Andersen and Bakken 2015). Using the data from the Oslo portion of the survey produces a total sample of 8461 individuals. The initial models have been run using linear regression, before further robustness testing of was done running logistic and multinomial regressions and finally including a smaller sample without the male respondents to test the effect of gender on the results.

\subsection{Dependent Variable}

The dependent variable is based on a question from the survey questionnaire on support for those travelling as foreign fighters to Syria ("To what degree do you support other adolescents who have travelled to Syria to fight (using weapons)?”) ${ }^{3}$.

\footnotetext{
3 In the original Norwegian survey question was as follows: "I hvor stor grad støtter du valget til de ungdommene—-som har dratt til Syria for å slåss (med våpen)?”
} 
Table 1 Response distribution: "To what degree do you support other adolescents who have travelled to Syria to fight (using weapons)?"

\begin{tabular}{lrc}
\hline & Freq & Percentage \\
\hline Not at all & 5004 & 59.14 \\
To a small degree & 1212 & 14.32 \\
To some degree & 852 & 10.07 \\
To a large degree & 290 & 3.43 \\
To a very large degree & 259 & 3.06 \\
Don't know & 844 & 9.98 \\
Total & 8461 & 100.00 \\
\hline
\end{tabular}

The question is potentially quite sensitive, as participation in violence abroad would be classified as illegal, and phrasing benefits from asking indirectly about the subject. By asking about others participation the question is slightly less threatening and functions as what Lee describes as "dejeopardizing" (1993). The aim of this approach is to minimise the respondents feeling of risk and jeopardy when asked about attitudes towards incriminating behaviour, a variation on the nominative technique ${ }^{4}$.

As the dependent variable is run using both linear, logistic and multinomial regression it has been coded with several different specification which is briefly presented below.

$D V I$. The first dependent variable is based on the original codings on the fivepoint scale. The item response consists of a five-point scale ranging from "Not at all”, "To a small degree", "To some degree", "To a large degree" to "To a very large degree" with a heavily skewed distribution which can be seen in Table 1.

DV II. The second dependent variable is a re-coded dichotomous variable based on the original five-point scale. The first two categories "Not at all" and "To a small degree" have been coded as non-supportive, while the categories from "To some degree" to "To a very large degree" are viewed as positive views to participation in fighting. This coding creates a dichotomous variable with 1401 respondents belonging to the category of interest, namely those who support travelling abroad to fight and 7060 individuals who do not. This relatively high percentage accounts for nearly $17 \%$ of the respondents, and most foreign fighters are believed to have joined jihadist groups (Weggemans et al. 2014), but it is not natural to assume that a willingness to fight in Syria equates with joining radical groups such as al-Nusra or ISIS. This makes the survey question less sensitive and more likely to obtain supportive answers. This is also one of the limitations of the data, as they do not allow for differentiation between support for groups with greater legitimacy and support for violent Islamist groups. There is also a category for those unable or unwilling to answer ("Don't know"). This category consists of $10 \%$ of the total respondents and will also

\footnotetext{
${ }^{4}$ For more information about sensitive survey questions see Lee (1993, ch.5).
} 
Table 2 Descriptive statistics

\begin{tabular}{lcccll}
\hline Variables & Obs & Mean & SD & Min. & Max. \\
\hline Armed struggle Syria & 8461 & .16 & .37 & 0 & 1 \\
Economic status & 8381 & 4.09 & .99 & 1 & 5 \\
Gender & 8316 & .54 & .499 & 0 & 1 \\
Criminal background & 8355 & .07 & .252 & 0 & 1 \\
Violence & 8405 & 1.19 & .588 & 1 & 5 \\
Religiosity & 8358 & 1.81 & 1.00 & 1 & 4 \\
Alienated & 2368 & 2.27 & 1.0945 & 1 & 5 \\
Disillusionment & 8340 & 3.66 & 1.154 & 1 & 5 \\
Muslim & 8461 & .17 & .377 & 0 & 1 \\
Believer & 8461 & .42 & .494 & 0 & 1 \\
Immigrant background & 8461 & .28 & .449 & 0 & 1 \\
\hline
\end{tabular}

be treated as non-supportive as it is impossible to discern the composition of this group. This might lead to underestimation of number of supportive respondents, but, as we are more interested in those willing to support foreign fighters, it would seem better to err on the side of caution when including respondents in the supportive category. This will be further discussed when running the models.

DV III. Because of the large positive response group in DV II, a second dichotomous variable is coded. The variable has a higher threshold for including respondents as positive and only individuals who responded, "To a large degree" and "To a very large" degree are coded as supportive, leaving all other respondents as nonsupportive. These two categories make up only just below $7 \%$ of the total sample (see Table 1), much lower than the distribution in DV II, but potentially a more relevant group.

$D V I V$. The final dependent variable has included specifications that includes the "Don't know" respondents, which make up approximately $10 \%$ of the total respondents (see Table 1), as a third category in the analysis. The variable follows the same specifications as in DV II, but includes the "Don't know" respondents as a separate group in addition to the "Non-supportive" and "Supportive", the dependent variable ends up with three inherently unordered categories, making it possible to run multinomial models with them as three separate categories in the models (Table 2).

\subsection{Independent Variables}

To test the hypotheses outlined by the theoretical framework, the following variables $^{5}$ have been included. The first independent variables are used to test the grievance and criminal explanatory model outlined by figures such as Olivier

\footnotetext{
5 Tolerance tests show that multicollinearity does not pose a significant problem to the main variables. The stepwise inclusion of independent variables should also help to uncover potential collinearity issues that might arise.
} 
Roy. Following this the variables included to test the assumed cultural or religious explanatory factors The role of previous criminal involvement is included and is measured to determine whether the respondent has previously been involved with the police because of illegal activities (CRIMINAL BACKGROUND). The variable does not specify the seriousness of these activities but focuses rather on the illicit nature of previous actions. The original variable measured the number of events on a five-point scale ${ }^{6}$. The variable has been coded as a dummy variable, with those who have never been in contact with the police because of criminal behaviour function as the reference category and those who reported at least one run in with the police "because of unlawful acts".

The socio-economic position variable(ECONOMIC STATUS (SES)) is based on self-described economic position of the respondent's family. This does not capture an objective sense of socio-economic status but provides insight into the respondent's own identification of his or her family's economic situation, often more central when considering the effect of socio-economic identity. The scale goes from 0 ("We have always been poor") to 5 ("We have always been well off").

The measurement of alienation or estrangement from Norwegian society (ALIEN$A T E D)$ is done creating a scale based on two Likert items that aim to capture whether respondents feel accepted by Norwegians or feel that Norwegians harbour negative emotions toward them (see Table 5) and which ranges from 1("Never") to 5("Very often"). The alienation variable looks at a smaller sample and includes only individuals from immigrant backgrounds. This presents certain limitations to the use of this in the modelling. for purposes of this article the variable has been included only in the last model and with little generalisability. While the variable does not capture the general population, it does capture the group that is statistically more likely to travel to Syria (Nesser 2016). To capture also a sense of dissatisfaction, a variable on feelings of general unhappiness with Norwegian society is included (DISILLUSIONMENT). The variable measures whether the respondent is unhappy with Norwegian society, which is a rather broad measure but should also capture ethnic Norwegians who could potentially view foreign fighting as an escape from a broader sense of dissatisfaction. The response categories range from 1("Very unhappy") to 5("Very happy").

As Pedersen et al. found, there seems to be a religious element to supporting armed struggle in Syria (2017), which might be explained by the conflict's sectarian nature. The Syrian conflict can be seen as mainly rooted in sectarian issues and has been used extensively by jihadist groups to attract support for their cause. This also follows the Kepel explanatory model, where cultural explanations are central for understanding the wave of radicalisation seen in the previous decade. The dummies for religious denomination are MUSLIMS and BELIEVERS, with nonbelievers as the reference category. The believer category encompasses those who identify with a Christian denomination, the majority religion, or a non-Muslim minority religion.

\footnotetext{
6 The original variable response categories were "Never", "Once", "2-5 times", "6-10" and "11 times or more"

7 Original version: "på grunn av noe galt du har gjort"
} 
To capture the sense of religious beliefs amongst respondents a measurement of the importance of religion in their daily life (RELIGIOSITY) is also included, measuring the subjective placement of religion in one's daily life from 1 ("Not important at all") to 4 ("Very important").

\subsection{Controls}

Some common factors that are identified in the literature as impacting attitudes towards violence have been included in the models as controls. Central here is demographic factors such as gender, age and educational levels. A dummy is included for (GENDER), with men as the reference category, based on the assumed gender gap in attitudes toward the use of violence and men are more likely to be involved in criminality. Age or educational levels are usually controlled for in similar studies but as the sampling for this survey includes only youths in their last year of high school these factors are not necessary. Participation in fights has also been included (VIOLENCE), as the literature indicates that a previous history of participating in violence might be important for understanding why some individuals have lower barriers for supporting the use of violence or participating in violence. The variable captures the number of violent fights the individual has been involved in-which is a relatively sensitive question-but still over $10 \%$ of the respondents indicate previous involvement (either once or more) at some previous point in time.

To control for a potential association between supporting travelling abroad to fight and support for the use of political violence closer to home, a variable has been constructed to measure support for political violence in Europe and Norway (POLITICAL VIOLENCE). The variable consists of the two items described in Table 6, about whether violence is justified to enact political change in Norway and Europe with responses from 1 ("Not at all") to 5 ("To a very large degree").

Also included is a variable on the IMMIGRANT background. To control for this, a dichotomous variable where those who either are born abroad or have parents who are born abroad is coded as 1 and ethnic Norwegians as the reference category. The number of individuals with immigrant backgrounds account for approximately $30 \%$ of the total sample. This corresponds well with the current percentage of individuals of immigrant background in Oslo as a whole (SSB 2020).

\section{Analysis}

The analysis will first go through the main models, starting with the bivariate models in the "Appendix", moving on to the main linear regression models. Following this the two dichotomous dependent variables (DV II and DV III) are tested in the logistic models to check the robustness of the initial findings before looking at the final dependent variable (DV IV) in the multinomial logistic regression. A final alternative model also looks at a potential gender divide in the initial findings, excluding young men from the sample. 
Table 3 DV I: Linear regression of attitudes towards fighting in Syria

\begin{tabular}{|c|c|c|c|c|c|c|}
\hline & (1) & (2) & (3) & (4) & (5) & (6) \\
\hline Violence & $\begin{array}{l}0.104 * * * \\
(0.027)\end{array}$ & $\begin{array}{l}0.121 * * * \\
(0.026)\end{array}$ & $\begin{array}{l}0.102 * * * \\
(0.028)\end{array}$ & $\begin{array}{l}0.101 * * * \\
(0.028)\end{array}$ & $\begin{array}{l}0.102 * * * \\
(0.027)\end{array}$ & $\begin{array}{l}0.127 * \\
(0.057)\end{array}$ \\
\hline Gender & $\begin{array}{l}0.00963 \\
(0.024)\end{array}$ & $\begin{array}{l}0.00526 \\
(0.024)\end{array}$ & $\begin{array}{l}0.00319 \\
(0.024)\end{array}$ & $\begin{array}{l}0.00332 \\
(0.024)\end{array}$ & $\begin{array}{l}0.00295 \\
(0.025)\end{array}$ & $\begin{array}{l}0.0186 \\
(0.052)\end{array}$ \\
\hline Immigrant background & $\begin{array}{l}0.0512 \\
(0.028)\end{array}$ & $\begin{array}{l}-0.0167 \\
(0.037)\end{array}$ & $\begin{array}{l}-0.0408 \\
(0.038)\end{array}$ & $\begin{array}{l}-0.0401 \\
(0.038)\end{array}$ & $\begin{array}{l}-0.0416 \\
(0.038)\end{array}$ & \\
\hline Political violence & $\begin{array}{l}0.321 * * * \\
(0.021)\end{array}$ & $\begin{array}{l}0.318 * * * \\
(0.020)\end{array}$ & $\begin{array}{l}0.317 * * * \\
(0.021)\end{array}$ & $\begin{array}{l}0.317 * * * \\
(0.021)\end{array}$ & $\begin{array}{l}0.317 * * * \\
(0.021)\end{array}$ & $\begin{array}{l}0.345 * * * \\
(0.036)\end{array}$ \\
\hline Self-reported SES & $\begin{array}{l}-0.0383^{* *} \\
(0.013)\end{array}$ & & $\begin{array}{l}-0.0364 * * \\
(0.013)\end{array}$ & $\begin{array}{l}-0.0361^{* *} \\
(0.013)\end{array}$ & $\begin{array}{l}-0.0366^{* *} \\
(0.013)\end{array}$ & $\begin{array}{l}-0.0516^{*} \\
(0.025)\end{array}$ \\
\hline Disillusionment & $\begin{array}{l}0.0195 \\
(0.011)\end{array}$ & & $\begin{array}{l}0.0166 \\
(0.011)\end{array}$ & $\begin{array}{l}0.0163 \\
(0.011)\end{array}$ & $\begin{array}{l}0.0169 \\
(0.011)\end{array}$ & $\begin{array}{l}0.0207 \\
(0.025)\end{array}$ \\
\hline Criminal background & $\begin{array}{l}0.152 * * \\
(0.059)\end{array}$ & & $\begin{array}{l}0.147 * \\
(0.059)\end{array}$ & $\begin{array}{l}0.0600 \\
(0.115)\end{array}$ & $\begin{array}{l}0.0974 \\
(0.085)\end{array}$ & $\begin{array}{l}0.177 \\
(0.127)\end{array}$ \\
\hline Religiosity & & $\begin{array}{l}0.0361 * \\
(0.018)\end{array}$ & $\begin{array}{l}0.0368 * \\
(0.018)\end{array}$ & $\begin{array}{l}0.0331 \\
(0.018)\end{array}$ & $\begin{array}{l}0.0369 * \\
(0.018)\end{array}$ & $\begin{array}{l}0.0110 \\
(0.028)\end{array}$ \\
\hline Believer & & $\begin{array}{l}0.0596^{*} \\
(0.027)\end{array}$ & $\begin{array}{l}0.0607 * \\
(0.028)\end{array}$ & $\begin{array}{l}0.0613^{*} \\
(0.028)\end{array}$ & $\begin{array}{l}0.0526 \\
(0.028)\end{array}$ & $\begin{array}{l}0.0377 \\
(0.079)\end{array}$ \\
\hline Muslim & & $\begin{array}{l}0.125^{*} \\
(0.055)\end{array}$ & $\begin{array}{l}0.116^{*} \\
(0.055)\end{array}$ & $\begin{array}{l}0.116^{*} \\
(0.055)\end{array}$ & $\begin{array}{l}0.119 * \\
(0.056)\end{array}$ & $\begin{array}{l}0.0672 \\
(0.084)\end{array}$ \\
\hline $\begin{array}{l}\text { Criminal } \\
\text { background*religiosity }\end{array}$ & & & & $\begin{array}{l}0.0478 \\
(0.059)\end{array}$ & & \\
\hline $\begin{array}{l}\text { Criminal } \\
\text { background*believer }\end{array}$ & & & & & $\begin{array}{l}0.128 \\
(0.122)\end{array}$ & \\
\hline $\begin{array}{l}\text { Criminal } \\
\text { background*Muslim }\end{array}$ & & & & & $\begin{array}{l}-0.0271 \\
(0.170)\end{array}$ & \\
\hline Alienated & & & & & & $\begin{array}{l}-0.0261 \\
(0.026)\end{array}$ \\
\hline Constant & $\begin{array}{l}1.087 * * * \\
(0.081)\end{array}$ & $\begin{array}{l}0.906^{* * * *} \\
(0.050)\end{array}$ & $\begin{array}{l}1.016^{* * *} \\
(0.085)\end{array}$ & $\begin{array}{l}1.023 * * * \\
(0.085)\end{array}$ & $\begin{array}{l}1.019 * * * \\
(0.085)\end{array}$ & $\begin{array}{l}1.092 * * * \\
(0.196)\end{array}$ \\
\hline$N$ & 6850 & 6949 & 6794 & 6794 & 6794 & 1782 \\
\hline$R^{2}$ & 0.077 & 0.077 & 0.079 & 0.079 & 0.079 & 0.106 \\
\hline
\end{tabular}

Standard errors in parentheses

$* p<0.05, * * p<0.01, * * * p<0.001$

The initial bivariate regressions are included in the "Appendix" and tests the direct relationship between the dependent variable (DV I) and the main independent variables without any of the controls (see Table 7). All the main independent variables have a significant relationship with support for fighting in Syria, apart from the disillusionment and alienation variables which show the expected 
directional relationship with the dependent variable but neither variable is significantly associated with support for foreign fighting.

Table 3 presents the findings from the main linear models with the first dependent variable (DV I). The first two models look at the effect of grievance and cultural factors separately, before all variables are included in model 3. The R-squared is relatively low, though not uncommonly so within the social sciences and especially behavioural studies (Neter et al. 1990). The control variables act in accordance with our expectations. Unsurprisingly, previous participation in violence and more positive attitudes about the use of political violence in general are both highly significant and positively associated with foreign fighting. The gender gap found in previous research on attitudes regarding political violence is not present in any of the initial models. The direction of the relationship is in accordance with the assumption that women are less likely to support those travelling abroad to fight, but not significantly so. Moving to the main findings of interest for the grievance variables in model 1 , the results provide some support for the initial hypotheses. The subjective economic identity variable plays a significant role across all the models and individuals who report a poorer economic situation are significantly more likely to support foreign fighting, though the actual effect of the included variable is relatively weak. The variable is also significant once the religious variables are also included in model 3 with a 0.04 increase in the predicted level of support for foreign fighting for every unit's increase, with individuals who view themselves as belonging to the poorest strata having a 0.2 increase in their predicted levels of support compared to those who view themselves as the most economically well off. While the practical effect the variable is relatively low, it lends some credence to $\mathrm{H}_{1}$. The significant association between economic identification and support for participation in foreign fighting is significant across all the three initial models. This differs from the findings of the Pedersen et al. (2017) study which used a more objective measurement of socio-economic position, rather than the subjective measurement included in these models.

The criminal background variable is significant across all of the models in Table 3, with criminal activity increasing the predicted support for foreign fighting with an approximately 0.15 unit-increase in the predicted level of support for foreign fighting amongst those with previous run-ins with the law. The variable is still significant when the religious variables are included in model 3, giving credence to $\mathrm{H}_{2}$. The lack of highly significant effects for the crime dummy variable might also be explained by the included economic status variable which is capturing some of the explanatory power of criminal background being a socio-economic phenomenon. Disillusionment with Norwegian society, on the other hand, was not significant by itself in the bivariate models and there is no significant effect in any of the main models, contradicting the assumptions in $\mathrm{H}_{3}$. While not significant, the variable shows the opposite association to what was initially posited and what was found in the bivariate model.

The religious factors are included in model 2 but provide some slightly mixed findings. Religiousness in the form of religiosity is slightly significant in most of the linear models. In the initial bivariate model religiosity was highly significant and shows the expected relationship with the dependent variable, but this weakens 
slightly once other variables are introduced in the linear model. While not a strong effect, religiosity seems to play a part and confirms the assumptions of $\mathrm{H}_{5}$ and that religious identity plays a role in explaining domestic attitudes towards foreign fighting in Syria. The religiosity variable measures a general sense of religious feeling, but looking more specifically at religious denominations reveals a broader religious identity playing into increased support. Religious denominations as a factor is significant, though not exactly as assumed in $\mathrm{H}_{6}$. Both believers in general and Muslims specifically are significantly more likely to support the armed participation in Syria, compared to non-believers or atheists. The willingness to support participation in armed struggle in Syria is therefore not unique for those who identify as Muslims but is also found amongst Christians and members of other religious groups. At the same time, the effect is stronger amongst Muslims in the models, with a 0.12 unitincrease in the predicted level of support, nearly double that of believers in general.

Models 4 and 5 test the interactive effect of grievances and religious factors but find little support for $\mathrm{H}_{7}$. While born-again religious identities following periods of criminality are often seen as explanations for increased willingness to participate in political violence, there is no association between this and support for the use of violence abroad in the models. While individuals with a criminal background in general have higher probabilities than those without a history of criminal behaviour, the gap increases as religiosity increases, but not to a significant degree.

The final model in Table 3 includes the alienation measure. No significant association is found for the alienation variable, giving little support to $\mathrm{H}_{4}$. An important caveat here is the limited scope of the sample of those who were asked questions about alienation. As mentioned previously, the alienation questions were put forward only to respondents where both parents were born outside Norway resulting in a much smaller sample $(N=1888)$. Ideally a similar alienation variable could be implemented for the entire sample, not just those with immigrant backgrounds. This makes it difficult to generalise from the changes to the other variables, as model 6 is looking only at a very limited group from the much larger sample. In general, there seem to be no substantial results for the alienation variable and few changes to the initial findings for the other variables in this model. Taken together the lack of findings for two of the more abstract grievance factors, namely alienation and disillusionment weakens some of the assumptions about the effect of a broader sense of disenfranchisement but seems rather to give more weight to more specific events such as previous run-ins with the police and low self-reported socio-economic status, rather than more abstract grievance measures.

\subsection{Robustness Testing}

To further expand on the main findings from the linear models and to test their robustness, the next step of the analysis will look at several alternative models, running the dependent variables with alternative specifications, as described in the previous data section. The first robustness models presented in Table 4 re-runs the original models with a re-coded dichotomous dependent variable (DV II), with respondents being coded as either "Supportive" or "Non-Supportive" of travelling to 
Table 4 DV II: Reported odds ratio from the logistic regression analyses of attitudes towards foreign fighting in Syria

\begin{tabular}{|c|c|c|c|c|c|c|}
\hline & (1) & (2) & (3) & (4) & (5) & (6) \\
\hline Violence & $\begin{array}{l}1.243 * * * \\
(0.068)\end{array}$ & $\begin{array}{l}1.266^{* * *} \\
(0.065)\end{array}$ & $\begin{array}{l}1.237 * * * \\
(0.068)\end{array}$ & $\begin{array}{l}1.236^{* * *} \\
(0.068)\end{array}$ & $\begin{array}{l}1.236 * * * \\
(0.068)\end{array}$ & $\begin{array}{l}1.234^{*} \\
(0.121)\end{array}$ \\
\hline Gender & $\begin{array}{l}0.980 \\
(0.067)\end{array}$ & $\begin{array}{l}0.961 \\
(0.065)\end{array}$ & $\begin{array}{l}0.959 \\
(0.066)\end{array}$ & $\begin{array}{l}0.960 \\
(0.066)\end{array}$ & $\begin{array}{l}0.959 \\
(0.066)\end{array}$ & $\begin{array}{l}1.061 \\
(0.137)\end{array}$ \\
\hline Immigrant background & $\begin{array}{l}1.093 \\
(0.080)\end{array}$ & $\begin{array}{l}0.946 \\
(0.092)\end{array}$ & $\begin{array}{l}0.891 \\
(0.088)\end{array}$ & $\begin{array}{l}0.892 \\
(0.088)\end{array}$ & $\begin{array}{l}0.890 \\
(0.088)\end{array}$ & $\begin{array}{l}1 \\
(.)\end{array}$ \\
\hline Political violence & $\begin{array}{l}1.774 * * * \\
(0.065)\end{array}$ & $\begin{array}{l}1.762 * * * \\
(0.063)\end{array}$ & $\begin{array}{l}1.767 * * * \\
(0.065)\end{array}$ & $\begin{array}{l}1.767 * * * \\
(0.065)\end{array}$ & $\begin{array}{l}1.767 * * * \\
(0.065)\end{array}$ & $\begin{array}{l}1.785 * * * \\
(0.104)\end{array}$ \\
\hline Self-reported SES & $\begin{array}{l}0.913^{* *} \\
(0.030)\end{array}$ & & $\begin{array}{l}0.916^{* *} \\
(0.030)\end{array}$ & $\begin{array}{l}0.917 * * \\
(0.030)\end{array}$ & $\begin{array}{l}0.916^{* *} \\
(0.030)\end{array}$ & $\begin{array}{l}0.877^{*} \\
(0.052)\end{array}$ \\
\hline Disillusionment & $\begin{array}{l}1.076^{*} \\
(0.032)\end{array}$ & & $\begin{array}{l}1.067^{*} \\
(0.032)\end{array}$ & $\begin{array}{l}1.067 * \\
(0.032)\end{array}$ & $\begin{array}{l}1.068^{*} \\
(0.032)\end{array}$ & $\begin{array}{l}1.092 \\
(0.064)\end{array}$ \\
\hline Criminal background & $\begin{array}{l}1.309 * \\
(0.167)\end{array}$ & & $\begin{array}{l}1.290 * \\
(0.166)\end{array}$ & $\begin{array}{l}1.128 \\
(0.279)\end{array}$ & $\begin{array}{l}1.142 \\
(0.240)\end{array}$ & $\begin{array}{l}1.431 \\
(0.354)\end{array}$ \\
\hline Religiosity & & $\begin{array}{l}1.047 \\
(0.048)\end{array}$ & $\begin{array}{l}1.042 \\
(0.048)\end{array}$ & $\begin{array}{l}1.035 \\
(0.049)\end{array}$ & $\begin{array}{l}1.042 \\
(0.048)\end{array}$ & $\begin{array}{l}1.010 \\
(0.070)\end{array}$ \\
\hline Believer & & $\begin{array}{l}1.256^{* *} \\
(0.101)\end{array}$ & $\begin{array}{l}1.257 * * \\
(0.102)\end{array}$ & $\begin{array}{l}1.259^{* *} \\
(0.102)\end{array}$ & $\begin{array}{l}1.230^{*} \\
(0.104)\end{array}$ & $\begin{array}{l}1.145 \\
(0.248)\end{array}$ \\
\hline Muslim & & $\begin{array}{l}1.488 * * \\
(0.207)\end{array}$ & $\begin{array}{l}1.474 * * \\
(0.208)\end{array}$ & $\begin{array}{l}1.477^{* *} \\
(0.208)\end{array}$ & $\begin{array}{l}1.475^{* *} \\
(0.212)\end{array}$ & $\begin{array}{l}1.261 \\
(0.292)\end{array}$ \\
\hline $\begin{array}{l}\text { Criminal } \\
\text { background*religiosity }\end{array}$ & & & & $\begin{array}{l}1.073 \\
(0.120)\end{array}$ & & \\
\hline $\begin{array}{l}\text { Criminal } \\
\text { background*believer }\end{array}$ & & & & & $\begin{array}{l}1.302 \\
(0.353)\end{array}$ & \\
\hline $\begin{array}{l}\text { Criminal } \\
\text { background*muslim }\end{array}$ & & & & & $\begin{array}{l}1.013 \\
(0.351)\end{array}$ & \\
\hline Alienated & & & & & & $\begin{array}{l}0.998 \\
(0.059)\end{array}$ \\
\hline Constant & $\begin{array}{l}0.0672 * * * \\
(0.014)\end{array}$ & $\begin{array}{l}0.0499 * * * \\
(0.006)\end{array}$ & $\begin{array}{l}0.0580 * * * \\
(0.012)\end{array}$ & $\begin{array}{l}0.0588 * * * \\
(0.013)\end{array}$ & $\begin{array}{l}0.0586^{* * *} \\
(0.013)\end{array}$ & $\begin{array}{l}0.0634 * * * \\
(0.028)\end{array}$ \\
\hline$N$ & 7289 & 7393 & 7229 & 7229 & 7229 & 1888 \\
\hline
\end{tabular}

Exponentiated coefficients; Standard errors in parentheses

$* p<0.05, * * p<0.01, * * * p<0.001$

participate in fighting in Syria. As seen in the distribution of the original dependent variable, the responses are highly skewed with approximately $60 \%$ responding "Not at all" to the question of whether they would support going to Syria to fight. There are few significant changes to the findings from the grievance variables, with criminal background and economic status, remaining significant.

For those who report always being well-off there is approximately a $30 \%$ decrease in odds of their supporting foreign fighting, compared to those who report always 
being poor ${ }^{8}$. Individuals with a criminal background are also $29 \%$ more likely to support foreign fighting, compared with those without a record. The disillusionment variable shows the same directional association with the dependent variable as in the original models. While the variable was not significantly so in the linear models, its effect is marginally significant in the logistic models. The effect of the variable is weaker than the other grievance factors but shows that the more satisfied an individual is, the more likely he or she is to support travelling out as a foreign fighter. This does not follow the expected logic of $\mathrm{H}_{4}$.

The findings from the religious variables remain unchanged. Both believers in general and Muslims specifically are more likely to support participation in the fighting, with the effect being stronger amongst individuals who identify as Muslim, at approximately $26 \%$ for believers in general compared to non-religious individuals and $48 \%$ for Muslims.

Table 8 (see "Appendix") applies a third dependent variable (DV III), which has also been coded as a dichotomous variable but with a higher threshold for being categorised as supportive of participating in foreign fighting. Because only those who strongly support travelling to fight in Syria are included as supportive the category is much smaller, making up only $7 \%$ of total respondents. This creates a highly skewed the dependent variable, and weakens the models. There is little significant connection between the traditional grievance factors, criminal background and strongly supporting foreign fighting, but its rather the sectarian factor that plays an explanatory role when studying those who strongly support travelling to fight.

The sectarian dimension of the conflict can perhaps in part help explain why religious background seems more important in these models, compared to the findings in the first logistic models in Table 4. Gender shows the same directional effect as the earlier logistic model but is significant here which indicates that women are less likely, compared to men, to strongly support foreign fighting in Syria. This follows the same pattern as with attitudes towards violence, where men in general are more open to the use of violence compared to women.

Following the logistic models, the final dependent variable (DV IV) is run, where the non-responsive "Don't know" respondents are included as a separate response category. In Table 9 (see "Appendix") these are analysed running multinomial logistic regression. The largest respondent group, "Non-supportive", is used as the reference category, while the results from the "Supportive" and "Don't know" response categories are modelled. The underlying logic of the multinomial modelling means the model compares the results from non-responsive individuals ("Don't know") and "Supportive" respondents relative to individuals in the "Non-supportive" reference category. The main findings of interest are the results from the "Don't know" models, which makes it possible to compare the "Non-supportive" and the "Don't know" categories. The lack of significant findings in this model indicates that there are few differences between non-respondents and those in the majority "Non-supportive" category.

$88.4 \%$ decrease in the odds for every units increase in self-reported socio-economic status in model 3 
There are only minor differences between the effect of the included variables in the "Don't know" model and the baseline model of those "Non-supportive". None of the main independent variables significantly differ between the "Don't know" and the "Non-supportive" groups. This lends support to the grouping of non-responding respondents with "Non-supportive" in the initial dichotomous coding of the dependent variable (DV II). Only two of the included variables differ significantly. Women have a higher probability of responding "Don't know" rather than giving a non-supportive response to the foreign fighting question, and the same effect can be seen amongst those willing to support political violence. The variable shows that increased support for the use of political violence in general makes it more likely that the individuals will respond "Don't know" rather than giving a non-supportive answer to the foreign fighter question. It is indicative of the highly sensitive nature of the question that some respondents move over to the "Don't know" category rather than give any explicit answer in any specific direction.

\subsubsection{Alternative Specification: Gender Gap}

The final models presented in Table 10 (see "Appendix") look closer at the gender dimension and tests the robustness of the initial findings by excluding the male respondents. Attitudes regarding violence are often viewed as a highly gendered phenomenon. The included gender variable in the original linear model does not find any major differences between men and women, but to test this further the models include only the female respondents. There are some indications that women seem not to be driven by the same motivating factors as men, with the dummy for Muslims being not significantly different from that for non-religious individuals. The same is true for the effect of criminal background, which is not significant in any of the models in Table 10. The effect of the other variables, such as self-reported socio-economic position is stronger for women than it was in the original models. In addition, the disillusionment variable becomes significant but still shows the opposite of the expected direction of the relationship, where individuals who are less disillusioned are more likely to support foreign fighting. At the same time this lack of finding can also be seen in connection with the different motivational factors inherent in male and female radicalisation. As previous research has highlighted there is a lack of reliable statistic on women and foreign fighting (Kvakhadze 2020), as well within radicalisation studies in general.

\section{Conclusion}

There has been an increased focus on the topic of foreign fighting in recent years, following the Syrian civil war and the outflow of fighters from Europe in the last decade. This article studies this phenomenon using the broader radicalisation 
literature as a framework, more specifically looking at factors identified by two central explanatory models ${ }^{9}$.

This study analyses some of the underlying grievances and religious factors that are thought to help to explain support for travelling abroad to fight in Syria. It has done so within a very specific context, namely amongst youths living in a wealthy, relatively homogeneous and stable Northern European city. In this context, the findings could potentially be of use for further studies on the phenomenon of foreign fighters in similar European countries and cities that have seen increased youth radicalisation, such as Belgium and the Netherlands. While the study does not capture the mechanism that explains the difference between those few individuals who end up leaving and those who support them, they share some common assumptions as presented in the literature review.

Amongst the findings one of the most salient seems to be the support for more traditional grievance explanations such as socio-economic identification and criminal background, which follows the Roy explanatory models where radical attitudes are more closely linked to criminality and grievances. The relatively weak findings for criminal background might also be explained by the fact that criminal background is a manifestation of underlying socio-economic issues which are by-andlarge captured by the included self-reported SES variable.

The lack of findings when it comes to some of the grievance variables, such as the lack of significance for alienation and the unexpected direction of the disillusionment variable in certain models, should be seen in light of the specific nature of the Syrian conflict. The Syrian conflict is characterised by a menagerie of actors, where supporting foreign fighters might also entail support for less radical groups fighting against the Assad regime. This is central for interpreting or attempting to generalise from the findings.

The lack of support for the interactive terms included in some of the models does also create an interesting quandary, because of the initial assumptions about the role of criminal background and the mediating effect of religious factors on this. This could perhaps be tested more diligently with a more accurate measure of changes in religious belief or identity, as the literature indicates that it is often swift conversion or a shift toward stricter religious interpretations and practices that best capture the phenomenon. Following the line of argument presented by researchers such as Kepel, this heightened sense of religiosity in meeting with grievances can prove important for understanding the radicalisation process.

In addition to studying these explanatory factors and how they impact willingness to support foreign fighting, this article also looks at some previously untested, to my knowledge, approaches to studying radicalisation using survey data. A common issue in survey studies of highly sensitive subjects, such as surveys on participation in violence or extremism, is that there are respondents who refuse to answer certain questions. In the case of the Young in Oslo data, there is an option of a "Don't know" response for those who did not answer the question about whether they support those travelling abroad to fight in Syria. The reasoning behind these non-responses

\footnotetext{
${ }^{9}$ See Nilsson (2019)
} 
might be many and the category is difficult to parse out. It will most likely consist of many different individuals, who found the sensitive question difficult to answer for a variety of reasons, but which would likely also contain some individuals who support foreign fighting but were unwilling to respond on the five-point scale. Many of the findings from this model support the inclusion of the non-responses in amongst those who do not support foreign fighting, as there are few differences in the effect of the independent variables on the two response categories.

The inclusion of the final models to test the robustness of the findings by excluding male respondents, giving some insight into the gendered nature of the explanatory factors. There are currently ongoing discussions, following the fall of the Islamic State caliphate, about women and the driving forces behind women who are willing to travel abroad to fight and whether these differ greatly from those found amongst men (Kvakhadze 2020). A gender gap in attitudes toward the use of political violence is not present, which might be explained by the survey question, which is focused on violence in a war zone rather than at home-a key difference which is likely to make it more permissible for women. At the same time, while the models in Table 10 indicate that the assumed explanatory factors are also highly significant amongst women, there are some interesting changes for religious factors and strengthening of certain grievance explanations which open up possibilities for future research on the gendered dimension of radical attitudes.

More generally there seems to be a trend across the different models for some of the grievance arguments, but also presents some of the data limitations when it comes to measuring a sense of alienation or disillusionment. Further studies on the topic of domestic support of foreign fighting necessitates a broader understanding and measurements of how individuals view themselves as part of larger social groups and a sense of marginalisation as part of this group. The lack of any significant findings for alienation might, in part, be explained by the lack of measures not just of alienation from something but also individual measures of belonging to something.

A potentially missing factor here is the political dimension that perhaps can better explain domestic support for foreign fighting. While the Syrian conflict has a sectarian element there is also a clear political dimension that this study is not able to capture, but which should be tested further. Attitudes towards political violence captures more radical ideas about necessary actions for political change and its highly significant relationship with all the dependent variables indicates that there is perhaps something further to capture here, outside of the traditional marginalisation and grievance literature.

\section{Appendix}

See Tables 5, 6, 7, 8, 9 and 10 
Table 5 The items used for measuring alienation

\begin{tabular}{ll}
\hline Item 1 & I don't feel accepted by Norwegians \\
Item 2 & I feel like Norwegians have something against me
\end{tabular}

Note: Response categories are:

1- "Never"; 2-"Rarely"; 3-"Sometimes"; 4-“Often"; 5-"Very often"
Table 6 The items used for measuring attitudes towards political violence

\begin{tabular}{ll}
\hline & "To what degree can the use of violence be justified" \\
\hline Item 1 & "...to create political change in Norway today?" \\
Item 2 & "...to create political change somewhere else in Europe?" \\
\hline
\end{tabular}

Note: Response categories are:

1-“Not at all”;2-“To a small degree";3-“To some degree”;4-“To a large degree"; 5-“To a very large degree"

Table 7 Bivariate linear models with main IVs

\begin{tabular}{|c|c|c|c|c|c|c|}
\hline & (1) & (2) & (3) & (4) & (5) & (6) \\
\hline Criminal background & $\begin{array}{l}0.372 * * * \\
(0.056)\end{array}$ & & & & & \\
\hline Self-reported SES & & $\begin{array}{l}-0.0650^{* * * *} \\
(0.013)\end{array}$ & & & & \\
\hline Religiosity & & & $\begin{array}{l}0.106 * * * \\
(0.013)\end{array}$ & & & \\
\hline Alienated & & & & $\begin{array}{l}0.0398 \\
(0.025)\end{array}$ & & \\
\hline Disillusionment & & & & & $\begin{array}{l}-0.0126 \\
(0.011)\end{array}$ & \\
\hline Muslim & & & & & & $\begin{array}{l}0.289 * * * \\
(0.039)\end{array}$ \\
\hline Believer & & & & & & $\begin{array}{l}0.0857 * * * \\
(0.025)\end{array}$ \\
\hline Constant & $\begin{array}{l}1.601 * * * \\
(0.012)\end{array}$ & $\begin{array}{l}1.895 * * * \\
(0.054)\end{array}$ & $\begin{array}{l}1.436 * * * \\
(0.025)\end{array}$ & $\begin{array}{l}1.676^{* * *} \\
(0.061)\end{array}$ & $\begin{array}{l}1.675 * * * \\
(0.042)\end{array}$ & $\begin{array}{l}1.547 * * * \\
(0.017)\end{array}$ \\
\hline$N$ & 7518 & 7548 & 7525 & 2107 & 7516 & 7617 \\
\hline$R^{2}$ & 0.008 & 0.004 & 0.010 & 0.001 & 0.000 & 0.009 \\
\hline
\end{tabular}

Standard errors in parentheses

$* p<0.05, * * p<0.01, * * * p<0.001$ 
Table 8 DV III: Reported odds ratio from the logistic regression analyses of attitudes towards foreign fighting in Syria

\begin{tabular}{|c|c|c|c|c|c|c|}
\hline & (1) & (2) & (3) & (4) & (5) & (6) \\
\hline Violence & $\begin{array}{l}1.219 * * \\
(0.092)\end{array}$ & $\begin{array}{l}1.262 * * * \\
(0.087)\end{array}$ & $\begin{array}{l}1.205^{*} \\
(0.092)\end{array}$ & $\begin{array}{l}1.205^{*} \\
(0.092)\end{array}$ & $\begin{array}{l}1.209^{*} \\
(0.091)\end{array}$ & $\begin{array}{l}1.274 \\
(0.159)\end{array}$ \\
\hline Gender & $\begin{array}{l}0.750 * * \\
(0.079)\end{array}$ & $\begin{array}{l}0.738 * * \\
(0.077)\end{array}$ & $\begin{array}{l}0.736^{* *} \\
(0.078)\end{array}$ & $\begin{array}{l}0.736^{* *} \\
(0.078)\end{array}$ & $\begin{array}{l}0.734 * * \\
(0.078)\end{array}$ & $\begin{array}{l}0.902 \\
(0.164)\end{array}$ \\
\hline Immigrant background & $\begin{array}{l}1.339 * * \\
(0.147)\end{array}$ & $\begin{array}{l}0.923 \\
(0.145)\end{array}$ & $\begin{array}{l}0.867 \\
(0.141)\end{array}$ & $\begin{array}{l}0.867 \\
(0.141)\end{array}$ & $\begin{array}{l}0.863 \\
(0.141)\end{array}$ & \\
\hline Political violence & $\begin{array}{l}1.745 * * * \\
(0.086)\end{array}$ & $\begin{array}{l}1.712 * * * \\
(0.083)\end{array}$ & $\begin{array}{l}1.724 * * * \\
(0.086)\end{array}$ & $\begin{array}{l}1.724 * * * \\
(0.086)\end{array}$ & $\begin{array}{l}1.724 * * * \\
(0.086)\end{array}$ & $\begin{array}{l}1.737 * * * \\
(0.130)\end{array}$ \\
\hline Self-reported SES & $\begin{array}{l}0.949 \\
(0.049)\end{array}$ & & $\begin{array}{l}0.964 \\
(0.050)\end{array}$ & $\begin{array}{l}0.964 \\
(0.050)\end{array}$ & $\begin{array}{l}0.962 \\
(0.050)\end{array}$ & $\begin{array}{l}0.971 \\
(0.083)\end{array}$ \\
\hline Disillusionment & $\begin{array}{l}1.056 \\
(0.049)\end{array}$ & & $\begin{array}{l}1.042 \\
(0.049)\end{array}$ & $\begin{array}{l}1.042 \\
(0.049)\end{array}$ & $\begin{array}{l}1.047 \\
(0.049)\end{array}$ & $\begin{array}{l}1.020 \\
(0.085)\end{array}$ \\
\hline Criminal background & $\begin{array}{l}1.285 \\
(0.233)\end{array}$ & & $\begin{array}{l}1.293 \\
(0.235)\end{array}$ & $\begin{array}{l}1.295 \\
(0.465)\end{array}$ & $\begin{array}{l}1.304 \\
(0.391)\end{array}$ & $\begin{array}{l}1.240 \\
(0.416)\end{array}$ \\
\hline Religiosity & & $\begin{array}{l}1.152^{*} \\
(0.077)\end{array}$ & $\begin{array}{l}1.162^{*} \\
(0.079)\end{array}$ & $\begin{array}{l}1.162^{*} \\
(0.082)\end{array}$ & $\begin{array}{l}1.162 * \\
(0.079)\end{array}$ & $\begin{array}{l}1.044 \\
(0.098)\end{array}$ \\
\hline Believer & & $\begin{array}{l}1.161 \\
(0.146)\end{array}$ & $\begin{array}{l}1.146 \\
(0.146)\end{array}$ & $\begin{array}{l}1.146 \\
(0.146)\end{array}$ & $\begin{array}{l}1.112 \\
(0.150)\end{array}$ & $\begin{array}{l}1.021 \\
(0.326)\end{array}$ \\
\hline Muslim & & $\begin{array}{l}1.705^{* *} \\
(0.339)\end{array}$ & $\begin{array}{l}1.671^{*} \\
(0.339)\end{array}$ & $\begin{array}{l}1.671^{*} \\
(0.339)\end{array}$ & $\begin{array}{l}1.769 * * \\
(0.367)\end{array}$ & $\begin{array}{l}1.391 \\
(0.435)\end{array}$ \\
\hline $\begin{array}{l}\text { Criminal } \\
\text { background*religiosity }\end{array}$ & & & & $\begin{array}{l}0.999 \\
(0.152)\end{array}$ & & \\
\hline $\begin{array}{l}\text { Criminal } \\
\text { background*believer }\end{array}$ & & & & & $\begin{array}{l}1.295 \\
(0.487)\end{array}$ & \\
\hline $\begin{array}{l}\text { Criminal } \\
\text { background*muslim }\end{array}$ & & & & & $\begin{array}{l}0.587 \\
(0.284)\end{array}$ & \\
\hline Alienated & & & & & & $\begin{array}{l}0.966 \\
(0.086)\end{array}$ \\
\hline Constant & $\begin{array}{l}0.0232 * * * \\
(0.007)\end{array}$ & $\begin{array}{l}0.0169 * * * \\
(0.003)\end{array}$ & $\begin{array}{l}0.0174 * * * \\
(0.006)\end{array}$ & $\begin{array}{l}0.0174 * * * \\
(0.006)\end{array}$ & $\begin{array}{l}0.0172 * * * \\
(0.006)\end{array}$ & $\begin{array}{l}0.0221^{* * *} \\
(0.014)\end{array}$ \\
\hline$N$ & 6850 & 6949 & 6794 & 6794 & 6794 & 1782 \\
\hline
\end{tabular}

Exponentiated coefficients; Standard errors in parentheses

$* p<0.05, * * p<0.01, * * * p<0.001$ 
Table 9 DV IV: Multinomial logit regression of attitudes towards fighting in Syria

\begin{tabular}{|c|c|c|c|c|c|c|}
\hline & (1) & (2) & (3) & (4) & (5) & (6) \\
\hline \multicolumn{7}{|l|}{ (“Support” category) } \\
\hline Violence & $\begin{array}{l}1.232 * * * \\
(0.068)\end{array}$ & $\begin{array}{l}1.258 * * * \\
(0.065)\end{array}$ & $\begin{array}{l}1.227 * * * \\
(0.068)\end{array}$ & $\begin{array}{l}1.227^{* * *} \\
(0.068)\end{array}$ & $\begin{array}{l}1.227 * * * \\
(0.068)\end{array}$ & $\begin{array}{l}1.229 * \\
(0.123)\end{array}$ \\
\hline Gender & $\begin{array}{l}1.005 \\
(0.069)\end{array}$ & $\begin{array}{l}0.985 \\
(0.067)\end{array}$ & $\begin{array}{l}0.983 \\
(0.068)\end{array}$ & $\begin{array}{l}0.984 \\
(0.068)\end{array}$ & $\begin{array}{l}0.983 \\
(0.068)\end{array}$ & $\begin{array}{l}1.097 \\
(0.142)\end{array}$ \\
\hline Immigrant background & $\begin{array}{l}1.085 \\
(0.080)\end{array}$ & $\begin{array}{l}0.951 \\
(0.093)\end{array}$ & $\begin{array}{l}0.893 \\
(0.089)\end{array}$ & $\begin{array}{l}0.894 \\
(0.089)\end{array}$ & $\begin{array}{l}0.893 \\
(0.089)\end{array}$ & \\
\hline Political violence & $\begin{array}{l}1.804 * * * \\
(0.067)\end{array}$ & $\begin{array}{l}1.791 * * * \\
(0.065)\end{array}$ & $\begin{array}{l}1.797 * * * \\
(0.067)\end{array}$ & $\begin{array}{l}1.797 * * * \\
(0.067)\end{array}$ & $\begin{array}{l}1.797 * * * \\
(0.067)\end{array}$ & $\begin{array}{l}1.814^{* * *} \\
(0.107)\end{array}$ \\
\hline Self-reported SES & $\begin{array}{l}0.911 * * \\
(0.030)\end{array}$ & & $\begin{array}{l}0.914 * * \\
(0.031)\end{array}$ & $\begin{array}{l}0.914 * * \\
(0.031)\end{array}$ & $\begin{array}{l}0.914 * * \\
(0.031)\end{array}$ & $\begin{array}{l}0.877 * \\
(0.052)\end{array}$ \\
\hline Disillusionment & $\begin{array}{l}1.073^{*} \\
(0.032)\end{array}$ & & $\begin{array}{l}1.064^{*} \\
(0.032)\end{array}$ & $\begin{array}{l}1.064 * \\
(0.032)\end{array}$ & $\begin{array}{l}1.065^{*} \\
(0.032)\end{array}$ & $\begin{array}{l}1.088 \\
(0.064)\end{array}$ \\
\hline Criminal background & $\begin{array}{l}1.302 * \\
(0.167)\end{array}$ & & $\begin{array}{l}1.284 \\
(0.167)\end{array}$ & $\begin{array}{l}1.171 \\
(0.292)\end{array}$ & $\begin{array}{l}1.180 \\
(0.249)\end{array}$ & $\begin{array}{l}1.410 \\
(0.352)\end{array}$ \\
\hline Religiosity & & $\begin{array}{l}1.040 \\
(0.048)\end{array}$ & $\begin{array}{l}1.037 \\
(0.048)\end{array}$ & $\begin{array}{l}1.031 \\
(0.050)\end{array}$ & $\begin{array}{l}1.037 \\
(0.048)\end{array}$ & $\begin{array}{l}1.005 \\
(0.071)\end{array}$ \\
\hline Believer & & $\begin{array}{l}1.273 * * \\
(0.103)\end{array}$ & $\begin{array}{l}1.273 * * \\
(0.104)\end{array}$ & $\begin{array}{l}1.274 * * \\
(0.104)\end{array}$ & $\begin{array}{l}1.249 * * \\
(0.106)\end{array}$ & $\begin{array}{l}1.141 \\
(0.249)\end{array}$ \\
\hline Muslim & & $\begin{array}{l}1.476 * * \\
(0.207)\end{array}$ & $\begin{array}{l}1.464 * * \\
(0.208)\end{array}$ & $\begin{array}{l}1.466 * * \\
(0.208)\end{array}$ & $\begin{array}{l}1.471 * * \\
(0.213)\end{array}$ & $\begin{array}{l}1.224 \\
(0.286)\end{array}$ \\
\hline $\begin{array}{l}\text { Criminal } \\
\text { background*religiosity }\end{array}$ & & & & $\begin{array}{l}1.047 \\
(0.119)\end{array}$ & & \\
\hline $\begin{array}{l}\text { Criminal } \\
\text { background*believer }\end{array}$ & & & & & $\begin{array}{l}1.223 \\
(0.334)\end{array}$ & \\
\hline $\begin{array}{l}\text { Criminal } \\
\text { background*Muslim }\end{array}$ & & & & & $\begin{array}{l}0.942 \\
(0.330)\end{array}$ & \\
\hline Alienated & & & & & & $\begin{array}{l}0.988 \\
(0.059)\end{array}$ \\
\hline Constant & $\begin{array}{l}0.0723 * * * \\
(0.015)\end{array}$ & $\begin{array}{l}0.0526 * * * \\
(0.006)\end{array}$ & $\begin{array}{l}0.0624 * * * \\
(0.014)\end{array}$ & $\begin{array}{l}0.0630 * * * \\
(0.014)\end{array}$ & $\begin{array}{l}0.0628 * * * \\
(0.014)\end{array}$ & $\begin{array}{l}0.0701 * * * \\
(0.031)\end{array}$ \\
\hline \multicolumn{7}{|l|}{ ("Don't know" category) } \\
\hline Violence & $\begin{array}{l}0.870 \\
(0.099)\end{array}$ & $\begin{array}{l}0.900 \\
(0.097)\end{array}$ & $\begin{array}{l}0.882 \\
(0.099)\end{array}$ & $\begin{array}{l}0.889 \\
(0.100)\end{array}$ & $\begin{array}{l}0.895 \\
(0.100)\end{array}$ & $\begin{array}{l}0.930 \\
(0.182)\end{array}$ \\
\hline Gender & $\begin{array}{l}1.399 * * \\
(0.145)\end{array}$ & $\begin{array}{l}1.389 * * \\
(0.142)\end{array}$ & $\begin{array}{l}1.401 * * \\
(0.147)\end{array}$ & $\begin{array}{l}1.400 * * \\
(0.147)\end{array}$ & $\begin{array}{l}1.398 * * \\
(0.146)\end{array}$ & $\begin{array}{l}1.603 * \\
(0.346)\end{array}$ \\
\hline Immigrant background & $\begin{array}{l}0.901 \\
(0.107)\end{array}$ & $\begin{array}{l}1.071 \\
(0.164)\end{array}$ & $\begin{array}{l}1.035 \\
(0.164)\end{array}$ & $\begin{array}{l}1.029 \\
(0.163)\end{array}$ & $\begin{array}{l}1.028 \\
(0.163)\end{array}$ & \\
\hline Political violence & $\begin{array}{l}1.218 * * \\
(0.082)\end{array}$ & $\begin{array}{l}1.226 * * \\
(0.082)\end{array}$ & $\begin{array}{l}1.225 * * \\
(0.082)\end{array}$ & $\begin{array}{l}1.226 * * \\
(0.082)\end{array}$ & $\begin{array}{l}1.226 * * \\
(0.082)\end{array}$ & $\begin{array}{l}1.222 \\
(0.143)\end{array}$ \\
\hline Self-reported SES & $\begin{array}{l}0.971 \\
(0.050)\end{array}$ & & $\begin{array}{l}0.967 \\
(0.050)\end{array}$ & $\begin{array}{l}0.965 \\
(0.050)\end{array}$ & $\begin{array}{l}0.967 \\
(0.050)\end{array}$ & $\begin{array}{l}0.998 \\
(0.099)\end{array}$ \\
\hline
\end{tabular}


Table 9 (continued)

\begin{tabular}{|c|c|c|c|c|c|c|}
\hline & (1) & (2) & (3) & (4) & (5) & (6) \\
\hline Disillusionment & $\begin{array}{l}0.954 \\
(0.042)\end{array}$ & & $\begin{array}{l}0.961 \\
(0.043)\end{array}$ & $\begin{array}{l}0.962 \\
(0.043)\end{array}$ & $\begin{array}{l}0.963 \\
(0.043)\end{array}$ & $\begin{array}{l}0.940 \\
(0.086)\end{array}$ \\
\hline Criminal background & $\begin{array}{l}0.928 \\
(0.215)\end{array}$ & & $\begin{array}{l}0.941 \\
(0.218)\end{array}$ & $\begin{array}{l}2.266 \\
(1.323)\end{array}$ & $\begin{array}{l}1.485 \\
(0.438)\end{array}$ & $\begin{array}{l}0.754 \\
(0.407)\end{array}$ \\
\hline Religiosity & & $\begin{array}{l}0.916 \\
(0.064)\end{array}$ & $\begin{array}{l}0.933 \\
(0.066)\end{array}$ & $\begin{array}{l}0.956 \\
(0.068)\end{array}$ & $\begin{array}{l}0.933 \\
(0.066)\end{array}$ & $\begin{array}{l}0.945 \\
(0.098)\end{array}$ \\
\hline Believer & & $\begin{array}{l}1.184 \\
(0.138)\end{array}$ & $\begin{array}{l}1.173 \\
(0.138)\end{array}$ & $\begin{array}{l}1.175 \\
(0.139)\end{array}$ & $\begin{array}{l}1.228 \\
(0.149)\end{array}$ & $\begin{array}{l}0.953 \\
(0.275)\end{array}$ \\
\hline Muslim & & $\begin{array}{l}0.880 \\
(0.192)\end{array}$ & $\begin{array}{l}0.901 \\
(0.199)\end{array}$ & $\begin{array}{l}0.899 \\
(0.199)\end{array}$ & $\begin{array}{l}0.969 \\
(0.218)\end{array}$ & $\begin{array}{l}0.665 \\
(0.192)\end{array}$ \\
\hline $\begin{array}{l}\text { Criminal } \\
\text { background*religiosity }\end{array}$ & & & & $\begin{array}{l}0.561 \\
(0.217)\end{array}$ & & \\
\hline $\begin{array}{l}\text { Criminal } \\
\text { background*believer }\end{array}$ & & & & & $\begin{array}{l}0.434 \\
(0.211)\end{array}$ & \\
\hline $\begin{array}{l}\text { Criminal } \\
\text { background*Muslim }\end{array}$ & & & & & $\begin{array}{l}0.209 \\
(0.223)\end{array}$ & \\
\hline Alienated & & & & & & $\begin{array}{l}0.869 \\
(0.099)\end{array}$ \\
\hline Constant & $\begin{array}{l}0.0792 * * * \\
(0.025)\end{array}$ & $\begin{array}{l}0.0589 * * * \\
(0.012)\end{array}$ & $\begin{array}{l}0.0784 * * * \\
(0.026)\end{array}$ & $\begin{array}{l}0.0747 * * * \\
(0.025)\end{array}$ & $\begin{array}{l}0.0745^{* * *} \\
(0.024)\end{array}$ & $\begin{array}{l}0.111^{* *} \\
(0.080)\end{array}$ \\
\hline$N$ & 7289 & 7393 & 7229 & 7229 & 7229 & 1888 \\
\hline
\end{tabular}

Exponentiated coefficients; Standard errors in parentheses

$* p<0.05, * * p<0.01, * * * p<0.001$ 
Table 10 Male respondents excluded, linear regression of attitudes towards fighting in Syria

\begin{tabular}{|c|c|c|c|c|c|c|}
\hline & (1) & (2) & (3) & (4) & (5) & (6) \\
\hline Violence & $\begin{array}{l}0.160 * * \\
(0.060)\end{array}$ & $\begin{array}{l}0.185 * * \\
(0.059)\end{array}$ & $\begin{array}{l}0.158 * * \\
(0.059)\end{array}$ & $\begin{array}{l}0.158 * * \\
(0.060)\end{array}$ & $\begin{array}{l}0.152^{*} \\
(0.059)\end{array}$ & $\begin{array}{l}0.226 \\
(0.119)\end{array}$ \\
\hline Immigrant background & $\begin{array}{l}0.0396 \\
(0.036)\end{array}$ & $\begin{array}{l}-0.0214 \\
(0.049)\end{array}$ & $\begin{array}{l}-0.0521 \\
(0.049)\end{array}$ & $\begin{array}{l}-0.0520 \\
(0.049)\end{array}$ & $\begin{array}{l}-0.0504 \\
(0.049)\end{array}$ & \\
\hline Political violence & $\begin{array}{l}0.350 * * * \\
(0.031)\end{array}$ & $\begin{array}{l}0.340 * * * \\
(0.031)\end{array}$ & $\begin{array}{l}0.349 * * * \\
(0.031)\end{array}$ & $\begin{array}{l}0.349 * * * \\
(0.031)\end{array}$ & $\begin{array}{l}0.349 * * * \\
(0.031)\end{array}$ & $\begin{array}{l}0.359 * * * \\
(0.048)\end{array}$ \\
\hline Self-reported SES & $\begin{array}{l}-0.0505^{* *} \\
(0.016)\end{array}$ & & $\begin{array}{l}-0.0474 * * \\
(0.016)\end{array}$ & $\begin{array}{l}-0.0474 * * \\
(0.016)\end{array}$ & $\begin{array}{l}-0.0474 * * \\
(0.016)\end{array}$ & $\begin{array}{l}-0.0990^{* *} \\
(0.033)\end{array}$ \\
\hline Disillusionment & $\begin{array}{l}0.0346^{*} \\
(0.014)\end{array}$ & & $\begin{array}{l}0.0301 * \\
(0.014)\end{array}$ & $\begin{array}{l}0.0300 * \\
(0.014)\end{array}$ & $\begin{array}{l}0.0295^{*} \\
(0.014)\end{array}$ & $\begin{array}{l}0.0584 \\
(0.033)\end{array}$ \\
\hline Criminal background & $\begin{array}{l}0.0973 \\
(0.085)\end{array}$ & & $\begin{array}{l}0.0837 \\
(0.086)\end{array}$ & $\begin{array}{l}0.0732 \\
(0.173)\end{array}$ & $\begin{array}{l}0.0481 \\
(0.121)\end{array}$ & $\begin{array}{l}-0.0687 \\
(0.211)\end{array}$ \\
\hline Religiosity & & $\begin{array}{l}0.0256 \\
(0.024)\end{array}$ & $\begin{array}{l}0.0284 \\
(0.024)\end{array}$ & $\begin{array}{l}0.0282 \\
(0.024)\end{array}$ & $\begin{array}{l}0.0287 \\
(0.024)\end{array}$ & $\begin{array}{l}0.0239 \\
(0.035)\end{array}$ \\
\hline Believer & & $\begin{array}{l}0.0801 * \\
(0.035)\end{array}$ & $\begin{array}{l}0.0809 * \\
(0.036)\end{array}$ & $\begin{array}{l}0.0810^{*} \\
(0.036)\end{array}$ & $\begin{array}{l}0.0798^{*} \\
(0.036)\end{array}$ & $\begin{array}{l}-0.0847 \\
(0.104)\end{array}$ \\
\hline Muslim & & $\begin{array}{l}0.140 \\
(0.073)\end{array}$ & $\begin{array}{l}0.138 \\
(0.073)\end{array}$ & $\begin{array}{l}0.138 \\
(0.073)\end{array}$ & $\begin{array}{l}0.130 \\
(0.073)\end{array}$ & $\begin{array}{l}0.00714 \\
(0.113)\end{array}$ \\
\hline $\begin{array}{l}\text { Criminal } \\
\text { background*religiosity }\end{array}$ & & & & $\begin{array}{l}0.00594 \\
(0.099)\end{array}$ & & \\
\hline $\begin{array}{l}\text { Criminal } \\
\text { background*believer }\end{array}$ & & & & & $\begin{array}{l}0.0250 \\
(0.168)\end{array}$ & \\
\hline $\begin{array}{l}\text { Criminal } \\
\text { background*muslim }\end{array}$ & & & & & $\begin{array}{l}0.176 \\
(0.354)\end{array}$ & \\
\hline Alienated & & & & & & $\begin{array}{l}-0.0193 \\
(0.034)\end{array}$ \\
\hline Constant & $\begin{array}{l}0.999 * * * \\
(0.112)\end{array}$ & $\begin{array}{l}0.822 * * * \\
(0.078)\end{array}$ & $\begin{array}{l}0.920 * * * \\
(0.117)\end{array}$ & $\begin{array}{l}0.921 * * * \\
(0.118)\end{array}$ & $\begin{array}{l}0.930 * * * \\
(0.117)\end{array}$ & $\begin{array}{l}1.054 * * * \\
(0.278)\end{array}$ \\
\hline$N$ & 3658 & 3707 & 3628 & 3628 & 3628 & 996 \\
\hline
\end{tabular}

Standard errors in parentheses

$* p<0.05, * * p<0.01, * * * p<0.001$

Funding Open Access funding enabled and organized by Projekt DEAL.

Data availability The data material used in this article is from a Ungdata-survey conducted by Norwegian Social Research (NOVA) in collaboration with the regional drug and alcohol competence centres (KoRus). Ungdata is financed by the Norwegian Directorate of Health. NOVA is not responsible for the analysis or interpretations done in this article.

Open Access This article is licensed under a Creative Commons Attribution 4.0 International License, which permits use, sharing, adaptation, distribution and reproduction in any medium or format, as long as 
you give appropriate credit to the original author(s) and the source, provide a link to the Creative Commons licence, and indicate if changes were made. The images or other third party material in this article are included in the article's Creative Commons licence, unless indicated otherwise in a credit line to the material. If material is not included in the article's Creative Commons licence and your intended use is not permitted by statutory regulation or exceeds the permitted use, you will need to obtain permission directly from the copyright holder. To view a copy of this licence, visit http://creativecommons.org/licen ses/by/4.0/.

\section{References}

Adida CL, Laitin DD, Valfort MA (2010) Identifying barriers to Muslim integration in France. Proc Nat Acad Sci 107(52):22384-22390

Ajzen I, Fishbein M (2005) The influence of attitudes on behavior. In: Albarracin D, Johnson BT, Zanna MP (eds) The handbook of attitudes. Lawrence Erlbaum Associates, New York, pp 173-221

Almond GA (1954) Appeals of communism. Princeton University Press, Princeton, NJ

Andersen PL, Bakken A (2015) Ung i Oslo 2015. Report at NOVA, Oslo

Bakker E (2006) Jihadi terrorists in Europe: their characteristics and the circumstances in which they joined the jihad: an exploratory study. Netherlands Institute of International Relations Clingendael, Den Haag

Bakker E (2011) Characteristics of jihadi terrorists in Europe (2001-2009). In: Coolsaet R (ed) Jihadi terrorism and the radicalisation challenge: European and American experiences. Ashgate, Aldershot, pp 131-144

Bakker E, de Bont R (2016) Belgian and Dutch Jihadist Foreign Fighters (2012-2015): characteristics, motivations, and roles in the war in Syria and Iraq. Small Wars Insurgen 27(5):837-857

Bakker E, Grol P (2015) Motives and Considerations of Potential Foreign Fighters from the Netherlands. ICCT policy brief at the International Centre for Counter-Terrorism, Den Haag

Bakker E, Paulussen C, Entenmann E (2013) Dealing with European Foreign fighters in Syria: governance challenges and legal implications. ICCT Research Paper, Den Haag

Basra R, Neumann PR (2016) Criminal pasts, terrorist futures: European jihadists and the new crimeterror nexus. Perspect Terror 10(6):25-40

Benmelech E, Klor EF (2016) What explains the flow of foreign fighters to ISIS? The National Bureau of Economic research working paper, Cambridge, MA

Berman E (2009) Radical, religious, and violent: the new economics of terrorism. MIT Press, Cambridge, MA

Committee on International Relations (2005) Islamic Terrorism in Europe. House of Representatives, Washington, DC

Coolsaet R (2016) Facing the fourth foreign fighters wave: what drives Europeans to Syria, and to Islamic State? Insights from the Belgian Case, Egmont Paper at The Royal Institute for International Relations, Brussels

Dalgaard Nielsen A (2010) Violent radicalization in Europe: what we know and what we do not know. Stud Conflict Terror 33(9):797-814

Dawson LL (2017) Discounting religion in the explanation of homegrown terrorism: a critique. In: Lewis JR (ed) The Cambridge companion to religion and terrorism. Cambridge University Press, Cambridge, pp 32-45

Dawson LL (2018) Challenging the curious erasure of religion from the study of religious terrorism. Numen 65(2-3):141-164

Dawson LL, Amarasingam A (2017) Talking to foreign fighters: insights into the motivations for Hijrah to Syria and Iraq. Stud Conflict Terror 40(3):191-210

Della Porta D (1992) Social movements and violence: participation in underground organisations. JAI Press, London

Doosje B, Loseman A, van den Bos K (2013) Determinants of Radicalization of Islamic Youth in the Netherlands: personal uncertainty, perceived injustice, and perceived group threat. J Soc Issues 69(3):586-604 
Duffy D (2009) Alienated radicals and detached deviants: What do the lessons of the 1970 Falls Curfew and the alienation- radicalisation hypothesis mean for current British approaches to counter-terrorism? Policy Stud 30(2):127-142

Europol (2016) Changes in modus operandi of Islamic State terrorist attacks. Tech. rep, Europol, Hague

Fromm E (1962) Alienation under Capitalism. In: Josephson E, Josephson M (eds) Man Alone: Alienation in Modern Society, Dell Publishing Co., New York, pp 56-73

Funk J, Elliott R, Urman M, Flores G, Mock R (1999) The attitudes towards violence scale. J Interpers Violence 14(11):1123-1136. https://doi.org/10.1177/088626099014011001

Hegghammer T (2010) Jihad in Saudi Arabia: violence and Pan-Islamism since 1979. Cambridge University Press, Cambridge

Hegghammer T (2010) The Rise of Muslim Foreign Fighters: Islam and the Globalization of Jihad. Int Secur 35(3):53-94

Hegghammer T (2013) Number of foreign fighters from Europe in Syria is historically unprecendented. Who should be worried? www.washingtonpost.com/news/monkey-cage/wp/2013/11/27/number-offoreign-fighters-from-europe-in-syria-is-historically-unprecedented-who-should-be-worried/

Kalyvas SN (2019) The landscape of political violence, Oxford University Press, pp 10-33. https://doi. org/10.1093/oxfordhb/9780198732914.013.1

Kepel G (2003) The origins and development of the Jihadist movement: From anti-communism to terrorism. Asian Affairs 34(2):91-108

Kepel G (2017) Terror in France: the rise of Jihad in the West. Princeton University Press, Princeton, NJ

Kvakhadze A (2020) Gendered and Jihad: women from the Caucasus in the Syrian conflict. Perspect Terror 14(2):69-79

Lee RM (1993) Doing research on sensitive topics. Sage Publications, Thousand Oaks, CA

Marone F (2016) Italian Jihadists in Syria and Iraq. J Terror Res 7(1):20-36

Marx K (1844) Economic \& Philosophic Manuscripts of 1844. www.marxists.org/archive/marx/works/ download/pdf/Economic-Philosophic-Manuscripts-1844.pdf

McCauley C, Moskalenko S (2008) Mechanisms of political radicalization: pathways toward terrorism. Terror Polit Violence 20(3):415-433. https://doi.org/10.1080/09546550802073367

Moghaddam FM (2005) The staircase to terrorism: a psychological exploration. Am Psychol 60(2):161-169

Moore C, Tumelty P (2008) Foreign fighters and the case of Chechnya: a critical assessment. Stud Conflict Terror 31(5):412-433

Murshed SM, Pavan S (2011) Identity and Islamic radicalization in western Europe. Civil Wars 13(3):259-279

Nesser P (2016) Islamist terrorism in Europe. C. Hurst \& Co., London

Nesser P, Stenersen A, Oftedal E (2016) Jihadi Terrorism in Europe: the IS-effect. Perspect Terror $10(6): 3-24$

Neter J, Wasserman W, Kutner MH (1990) Applied linear regression models. Irwin, Homewood, IL

Neumann PR (2015) Foreign fighter total in Syria/Iraq now exceeds 20,000; surpasses Afghanistan conflict in the 1980s. https://icsr.info/2015/01/26/foreign-fighter-total-syriairaq-now-exceeds-20000 -surpasses-afghanistan-conflict-1980s/

Nilsson M (2019) Motivations for Jihad and cognitive dissonance: a qualitative analysis of former Swedish Jihadists. Studies in Conflict \& Terrorism, pp 1-19

Oppetit A, Campelo N, Bouzar L, Pellerin H, Hefez S, Bronsard G, Bouzar D, Cohen D (2019) Do radicalized minors have different social and psychological profiles from radicalized adults? Front Psychiatry 10

Pedersen W, Vestel V, Bakken A (2017) At risk for radicalization and jihadism? A population-based study of Norwegian adolescents. Cooperation \& Conflict, pp 1-23

Pokalova E (2019) Driving factors behind foreign fighters in Syria and Iraq. Stud Conflict Terror 42(9):798-818

Ransford HE (1968) Isolation, powerlessness, and violence: a study of attitudes and participation in the Watts Riot. Am J Soc 73(5):581-591

Rostami A, Sturup J, Mondani H, Thevselius P, Sarnecki J, Edling C (2020) The Swedish Mujahideen: an exploratory study of 41 Swedish foreign fighters deceased in Iraq and Syria. Stud Conflict Terror 43(5):382-395

Roy O (2015) What is the driving force behind jihadist terrorism? A scientific perspective on the causes/ circumstances of joining the scene. At the Bundeskriminalamt Autumn Conference

Roy O (2016) Can We Understand the Motives of Jihadists? Pouvoirs No 158(3):15-24 
Roy O (2017) Jihad and death: the global appeal of Islamic State. Hurst \& Company, London Schwartz DC (1973) Political alienation and political behavior. Transaction Publishers, London Seeman M (1959) On the meaning of alienation. Am Sociol Rev 24(1):783-791

Sheikh J (2016) "I Just Said It. The State": examining the motivations for Danish foreign fighting in Syria. Perspect Terror 10(6):59-67

Silber MD, Bhatt A (2007) Radicalization in the West: the Homegrown Threat. NYPD Report, New York

Skilicorn DB, Leuprecht C, Winn C (2012) Homegrown Islamist radicalization in Canada: process insights from an attitudinal survey. Can J Polit Sci 45(4):929-956

SSB (2020) Immigrants and Norwegian-born to immigrant parents, by immigration category, country background and percentages of the population (M) 2010-2020. http://www.ssb.no/en/statbanken/ statbank/table/09817/

Steinkellner A (2020) Nesten 15 prosent er innvandrere. https://www.ssb.no/befolkning/artikler-og-publi kasjoner/nesten-15-prosent-er-innvandrere, Oslo, SSB

Stewart F (2000) Crisis prevention: tackling horizontal inequalities. Oxf Dev Stud 28(3):245-262

Stewart F (2016) Horizontal inequalities and conflict: understanding group violence in multiethnic societies. Palgrave Macmillan, London

The Soufan Group (2015) Foreign fighters: an updated assessment of the flow of foreign fighters into Syria and Iraq. The Soufan Group Report, New York, NY

van Bergen D, Feddes AR, Doosje B, Pels TVM (2015) Collective identity factors and the attitude toward violence in defense of ethnicity or religion among Muslim youth of Turkish and Moroccan Descent. Int J Intercult Relat 47(1):89-100

Vassenden K (ed) (1997) Innvandrere i Norge: hvem er de, hva gjør de og hvordan lever de? Statistiske analyser, Statistical analyses, Statistisk sentralbyrå, Oslo

Verwimp P (2016) Foreign fighters in Syria and Iraq and the socio-economic environment they faced at home: a comparison of European countries. Perspect Terror 10(6):68-81

Weggemans D, Bakker E, Grol P (2014) Who are they and why do they go? The radicalization and preparatory processes of Dutch Jihadist foreign fighters. Perspect Terror 8(4):100-110

Publisher's Note Springer Nature remains neutral with regard to jurisdictional claims in published maps and institutional affiliations. 